\title{
Hyper Converged Systems Applied (HSA) Methodology to Optimize the Process of Technological Renewal in Data Centers
}

\author{
Andy Reyes, Ciro Rodriguez, Doris Esenarro
}

\begin{abstract}
This paper proposes to improve the process of technological renewal in data centers with the implementation of hyperconverged systems, through the virtualization of physical equipment, networks, storage and systems, to achieve cost reduction in critical areas such as: maintenance, consumption of energy, data center space and the optimization of the resources necessary for the administration and specialization of the IT team. The proposed methodology HSA (Hyperconverged Systems Applied), considers the planning and implementation of an integral IT architecture that combines software with high-level servers that can host systems capable of providing support and continuity of IT services, to design, implement and manage the technology in an orderly manner, reducing management efforts and increasing the organization's ability to support new projects. According to the results obtained with the application of the HSA methodology, it was reduced the size of virtualized systems by an average of $33.33 \%$ and the amount of non-virtualized technology by an average of $44.33 \%$, depending on the cases evaluated was increased the level of IT team experience at $56.67 \%$ when managing more technology with less staff.
\end{abstract}

Keywords: Hyperconverged systems, methodology, IT architecture, IT services, Data Center.

\section{INTRODUCTION}

Hyperconvergence is a technological alternative where data center systems and enterprise applications are hosted, although there are different alternatives, such as local implementations of traditional servers such as racks, towers, blades, cloud systems, etc., defined in international standards [1] the methodologies that allow these implementations are not common, that is, when implement these solutions, think more of an installation than of a design.

The objective of this research is to propose a methodology that can serve as a guide for the implementation of hyperconvergent solutions, since this methodology is based on open standards and is not intended to be exclusive to a specific manufacturer, it even aligns with the state contracting laws from many countries whose fundamental principles are the plurality of manufacturers and the evaluation of solutions based on open source.

Revised Version Manuscript Received on 16 September, 2019.

Andy Reyes, Open Nova IT Consulting, E-Mail: andy. reyes @ opennova.pe

Ciro Rodriguez, National University of San Marcos, Peru, South America, E-Mail: crodriguezro@ unmsm.edu.pe

Doris Esenarro, National University Federico Villarreal, Peru, South America, E-Mail: desenarro@unfv.edu.pe

\section{PUBLIC SECTOR AND GOVERNMENT DATA CENTER TRENDS}

If look for contracting processes in Peru in SEACE[2] (Electronic System of Government Procurement), in Colombia in SECOP[3] (Electronic System for Public Procurement) and in Ecuador in SOCP[4] (Official Public Procurement System), find processes for the acquisition of technological solutions from data centers where solutions based on blades or racks servers are requested, however most of the terms of reference detail the final product, that is, the system with the amount and capacity of resources, but they do not present technological designs, implementation plans, migration plans, contingency plans, among others.

When read these documents, do not notice a substantial difference between the purchase of equipment for a specific service and the purchase of a solution that must be integrated into an infrastructure that was already implemented in previous processes with scaling, guarantee and continuous operation capabilities.

When implement this technology in a company, must consider that hyperconverged infrastructure could be integrated with previously implemented platforms, Ortiz [5] classifies data centers that should not be interrupted in 3rd category, that is, they can be migrated to a hyperconvergent platform and continue to maintain operations in a non-disruptive manner, in addition to taking into account good security practices and continuity of operations.

\section{WHAT IS HYPERCONVERGENCE AND WHY IS A METHODOLOGY REQUIRED?}

Hyperconvergence and convergence reduce traditional implementations of data centers where components are separated, convergence integrates these components so that they can logically be seen as one, hyperconvergence integrates these separate components through a software layer on the same physical server, leaving to this layer high availability and scaling of these physical servers to integrate through the software.

Systems hyperconvergence refers to the integration of the components of a server platform (computing, networks and storage) through virtualization technology, however, the manufacturers of these technologies present their own

Published By:

Blue Eyes Intelligence Engineering

\& Sciences Publication

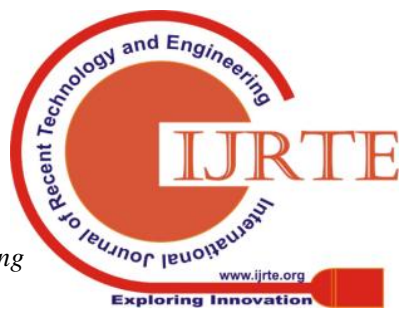


virtualization methodologies, that is, If take as an example from VMware [6], this presents the methodology VIM (Virtual Infrastructure Methodology) as a proposal, reviewing the documentation of this methodology, see that it is oriented exclusively to this manufacturer.

This is repeated with the main manufacturers of virtualization and hyperconvergence technologies such as IBM, HP, Nutanix, etc., as contemplated in [7], in these cases an implementation methodology is necessary is important, especially if government regulations do not allow the purchase of a specific technology without a previous evaluation process.

The proposal which will call HSA Methodology[8] (Hyperconverged Systems Applied) as well as the systems implementation methodologies, is a consolidated one of good practices and other similar methodologies, in addition to defining phases that allow the evaluation of technological alternatives where at least one (1) must be open source and can provide documentation such as computer designs, storage designs, network designs and the roles associated with the implementation, execution and maintenance of these designs.

These documents can be included as annexes in the government procurement processes in order to calculate more accurately the effort of the engineering work by the suppliers and can make more precise proposals and avoid excessive costs due to poorly defined scope.

The other documents that the methodology propose will serve to meet the requirements of the standards required by organizations, which are mostly based on ISO standards.

\section{PROPOSED METHODOLOGY}

The research process, as is show in Figure 1., explain that the proposed HSA methodology is based on the development of the three research variables. The intervinent variable wich is the main contribution of this research. The best infrastructure practices related to hyperconvergence are consolidated and integrated into the researcher's experience with the scientific method to finally develop the proposed HSA methodology.



Figure. 1. Research Process

The HSA methodology presents phases that facilitate its implementation in the company, as shown in Table 1. In these phases the technological alternatives available in the region are evaluated and the market study is carried out based on a comparison of prices, times and complexity of implementation.

\section{Table 1. Phases}

\begin{tabular}{|l|l|}
\hline \multicolumn{1}{|c|}{ Phase } & \multicolumn{1}{|c|}{ Description } \\
\hline evaluation & $\begin{array}{l}\text { The technological alternatives are } \\
\text { evaluated where at least one must be open } \\
\text { source and the alternative that meets the } \\
\text { requirements of the organization is } \\
\text { selected }\end{array}$ \\
\hline $\begin{array}{l}\text { Planning and } \\
\text { design }\end{array}$ & $\begin{array}{l}\text { Computing, network and storage designs } \\
\text { are made. In the case of integrating with } \\
\text { another platform, integration and } \\
\text { migration designs of pre-existing systems } \\
\text { are considered. }\end{array}$ \\
\hline Implementation & $\begin{array}{l}\text { The execution of the plans defined in the } \\
\text { previous phase and the tests confirming } \\
\text { the correct functioning of the systems are } \\
\text { carried out. }\end{array}$ \\
\hline $\begin{array}{l}\text { Continuous } \\
\text { administration }\end{array}$ & $\begin{array}{l}\text { Routine administration, backup, } \\
\text { maintenance and continuous improvement } \\
\text { processes of the implemented platform are } \\
\text { carried out }\end{array}$ \\
\hline
\end{tabular}

Domains are groups of technologies that must be designed and implemented, as shown in Table 2.

Table 2. Domains

\begin{tabular}{|l|l|}
\hline \multicolumn{1}{|c|}{ Domain } & \multicolumn{1}{|c|}{ Description } \\
\hline $\begin{array}{l}\text { Communication } \\
\text { networks }\end{array}$ & $\begin{array}{l}\text { Present virtual networks and quality of } \\
\text { services in order to prioritize traffic }\end{array}$ \\
\hline Storage systems & $\begin{array}{l}\text { Define storage profiles according to } \\
\text { transactionality and storage capacity }\end{array}$ \\
\hline $\begin{array}{l}\text { Operating } \\
\text { systems }\end{array}$ & $\begin{array}{l}\text { Present the list of templates of the } \\
\text { operating systems available to host } \\
\text { business applications }\end{array}$ \\
\hline System security & $\begin{array}{l}\text { Apply the security guidelines defined by } \\
\text { the organization in the networks, } \\
\text { computer and storage components }\end{array}$ \\
\hline $\begin{array}{l}\text { High } \\
\text { availability }\end{array}$ & $\begin{array}{l}\text { Define disaster recovery rules in order to } \\
\text { give continuity to the components defined } \\
\text { in the previous domains }\end{array}$ \\
\hline $\begin{array}{l}\text { Infrastructure } \\
\text { scalability }\end{array}$ & $\begin{array}{l}\text { Prepare the infrastructure to allow to grow } \\
\text { in hyperconvergence nodes, networks, } \\
\text { storage or any scalable component }\end{array}$ \\
\hline
\end{tabular}

Each domain considers a different effort in each phase since this is conditioned to the type of project and the regulations that the institution has implemented, for example in a financial or tax entity the domain of systems security represents a greater effort because security policies of information are audited by some superintendent, in a service provider, the communications networks phase implies a greater effort because it must be integrated into more than one regional communications provider.

Can define the documentation and roles involved by each phase, as shown in Table 3. 
Table 3. Documents and roles

\begin{tabular}{|l|l|l|}
\hline Phase & Document & Role \\
\hline Requirements evaluation & $\begin{array}{l}\text { Infrastructure inventory } \\
\text { Evaluation report of proposed technologies } \\
\text { Hyperconvergence Technology Choice Report }\end{array}$ & Infrastructure analyst \\
\hline Planning and design & $\begin{array}{l}\text { Conceptual, logical and physical infrastructure design. } \\
\text { Design of services, administration and storage networks } \\
\text { Design of physical and virtual system profiles } \\
\text { Design of profiles, levels and storage capacities } \\
\text { Test plan } \\
\text { Migration plan } \\
\text { Implementation project plan }\end{array}$ & $\begin{array}{l}\text { Infrastructure analyst } \\
\text { IT project manager }\end{array}$ \\
\hline Implementation & $\begin{array}{l}\text { Technology domains implementation report } \\
\text { Tests execution report } \\
\text { Platform migration report }\end{array}$ & \\
& $\begin{array}{l}\text { Platform Administration Guide } \\
\text { Backup and recovery procedures } \\
\text { Platform Assurance Guide }\end{array}$ & \\
\hline $\begin{array}{l}\text { Continuous } \\
\text { administration }\end{array}$ & Infrastructure specialist \\
\hline
\end{tabular}

The phases and domains can, as shown in Figure 2., are notation [9]. carried out according to the following workflow in BPM

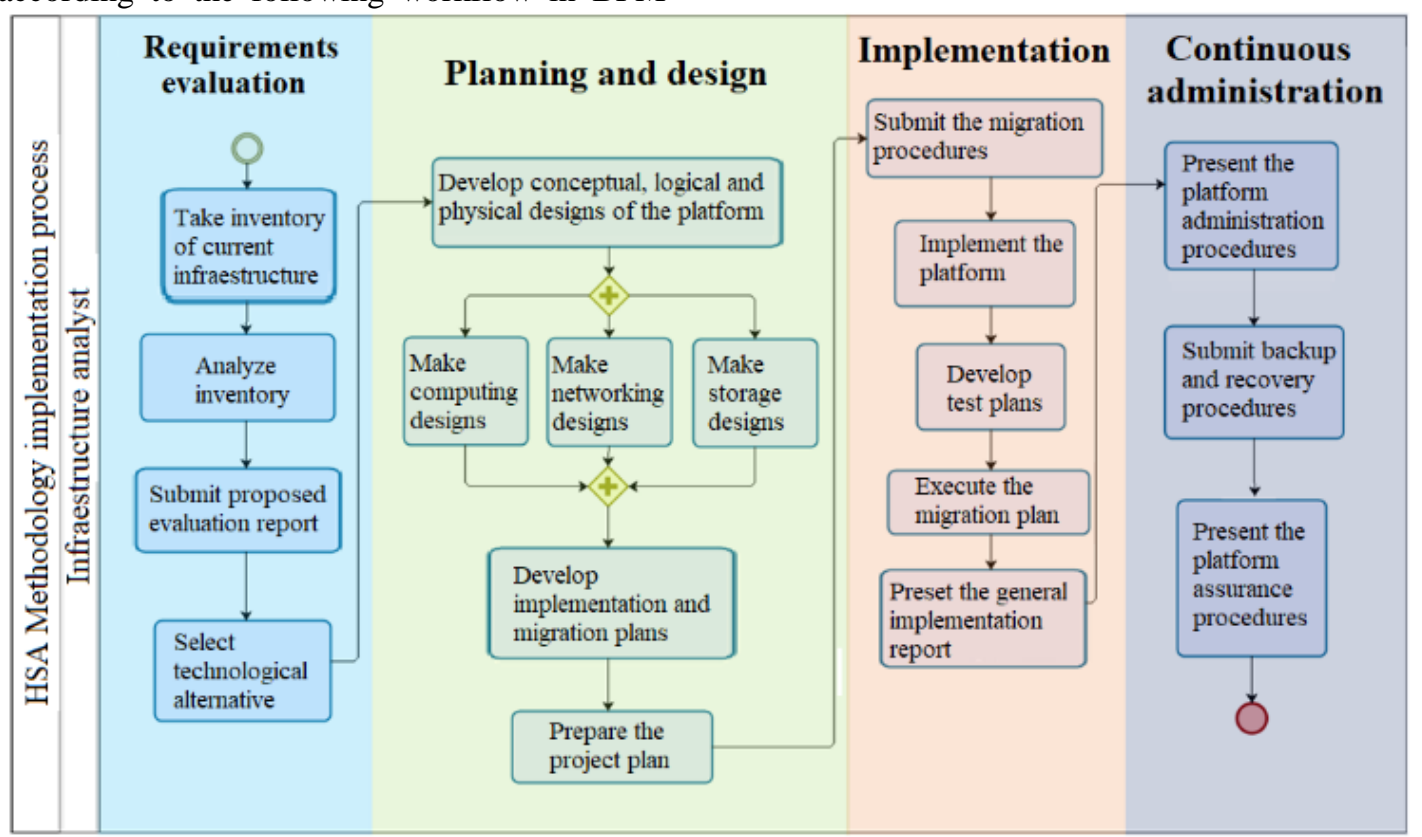

Figure. 2. HSA methodology workflow

\section{RESEARCH PROCESS}

\section{SUCCESS CASES AND PROMOTERS OF TECHNOLOGY}

Hyperconvergence success cases in Latin America and the world are led by the specialized provider Nutanix, however, hardware vendors such as IBM, HP and Dell have a considerable market.

There are virtualization solutions with hyperconvergence option such as VMware vSphere with integration to vSan, can also refer to the oVirt open source project with integration to gluster or another open source project with enterprise support like RedHat Virtualization with integration to RedHat Gluster Storage.

All the mentioned options are viable to implement the hyperconvergent platform that can support enterprise applications in an environment with high availability and scalability.
The research begins with the description of the process of technological renewal in data centers, then through interviews and comparison with similar researches can identify the difference between the current situation (AS-IS) and the expected situation (TO-BE), as shown in Table 4., and determine the research question.

The general results can be separated into specific results through indicators of the process of technological renewal in data centers, not all companies have the same results, however, companies that do not yet virtualize can improve these indicators much more, this is a case of a government company that already virtualizes on VMware vSphere platform.Each indicator presents goals expected in a very general way by interviewed in the organization, being the main interviewee the $\mathrm{CIO}$, is already the one who interacts as a beneficiary of the process without participating directly in it, but through his specialists in the technological domains. 
Table 4. As-is vs To-be

\begin{tabular}{|l|l|}
\hline \multicolumn{1}{|c|}{ AS-IS } & \multicolumn{1}{c|}{ TO-BE } \\
\hline $\begin{array}{l}\text { High validation times for } \\
\text { each of the technological } \\
\text { domains - 166 days }\end{array}$ & $\begin{array}{l}\text { Shorter times in validation of } \\
\text { each of the technological } \\
\text { domains - 135 days }\end{array}$ \\
\hline $\begin{array}{l}\text { High renovation cost - US \$ } \\
\text { 250,000.00 }\end{array}$ & $\begin{array}{l}\text { Reduced costs in } \\
\text { technological renovation - } \\
\text { US \$ 150,000.00 }\end{array}$ \\
\hline $\begin{array}{l}\text { Number of IT systems in } \\
\text { production - 100 }\end{array}$ & $\begin{array}{l}\text { Number of IT systems in } \\
\text { production - 90 }\end{array}$ \\
\hline $\begin{array}{l}\text { High number of technologies } \\
\text { implemented - 15 }\end{array}$ & $\begin{array}{l}\text { Reduced number of } \\
\text { technologies implemented - } \\
12\end{array}$ \\
\hline $\begin{array}{l}\text { IT staff specialization level - } \\
5\end{array}$ & $\begin{array}{l}\text { IT staff specialization level - } \\
12\end{array}$ \\
\hline
\end{tabular}

Through the previous analysis, the research question is defined as:

- Why is the process of technological renewal in data centers not carried out as expected?

So the objective of the research is:

- Improve the process of technological renewal in data centers.

Finally, the hypothesis involves the variables defined in Fig. 1., the main contribution of this research being the HSA Methodology due to the complexity that the hyperconvergence implementation implies, this methodology presents a guide that facilitates the process, concluding in the research hypothesis:

- The implementation of hypercovergent systems through the HSA Methodology allows to improve the process of technological renewal in data centers.

The best way to contrast the hypothesis proposed, is to measure the indicators, as shown in Table 5., these measurements should be made in one situation without applying the proposed methodology and in another situation applying the proposed methodology, through techniques and statistical software can determine if HSA methodology supports to meet the proposed objective.

Table 5. Process indicators

\begin{tabular}{|l|l|l|l|}
\hline Indicator & Index & $\begin{array}{l}\text { Measure } \\
\text { ment unit }\end{array}$ & $\begin{array}{l}\text { Observati } \\
\text { on unit }\end{array}$ \\
\hline $\begin{array}{l}\text { Process } \\
\text { time }\end{array}$ & {$[1 . .180]$} & Days & $\begin{array}{l}\text { Project } \\
\text { plan }\end{array}$ \\
\hline $\begin{array}{l}\text { Renewal } \\
\text { Cost }\end{array}$ & $\begin{array}{l}{[100,000 . .} \\
300,000]\end{array}$ & $\begin{array}{l}\text { American } \\
\text { dollars }\end{array}$ & $\begin{array}{l}\text { Supplier } \\
\text { Quote }\end{array}$ \\
\hline $\begin{array}{l}\text { Size of the } \\
\text { IT } \\
\text { platform in } \\
\text { production }\end{array}$ & {$[1 . .500]$} & IT systems & $\begin{array}{l}\text { Data } \\
\text { center } \\
\text { architectur } \\
\text { e design }\end{array}$ \\
\hline $\begin{array}{l}\text { Number of } \\
\text { IT } \\
\text { technologi } \\
\text { es } \\
\text { implement } \\
\text { ed }\end{array}$ & {$[1 . .15]$} & Units & $\begin{array}{l}\text { Data } \\
\text { center } \\
\text { architectur } \\
\text { e design }\end{array}$ \\
\hline $\begin{array}{l}\text { Level of } \\
\text { IT staff } \\
\text { specializat } \\
\text { ion }\end{array}$ & {$[1 . .15]$} & Units & HR reports \\
\hline
\end{tabular}

\section{RESEARCH PROCESS RESULTS}

With the application of the HSA Methodology, can reduce the cost of implementing the data center, this is very important in government procurement since the laws provide that, given technologies with similar benefits, the economic factor is predominant.

Not only must carry out an analysis of the cost of implementing hyperconvergence technologies, but also make the comparison of maintaining older technologies since in many cases the cost of maintaining old technology is greater than the cost of renewal.

Although the redundancy of physical components is much discussed, this is the responsibility of the hardware vendor, however the high availability domain suggests that the hyperconverged platform must have at least 3 physical nodes to guarantee the use of $66.67 \%$ of the infrastructure, leaving $33.33 \%$ waiting to be initiated by automated processes. High availability improves with the implementation of more physical nodes.

Must take into account that systems, applications or software with certification on virtualized platforms, have a high probability of success of being migrated to hyperconvergence platforms, systems that depend on specific hardware or license are excluded.

The benefits of hyperconvergence are greater in companies that do not virtualize yet, however companies that already virtualize also obtain benefits, in the second case platform migration activities are no longer optional and become mandatory.

Finally, a company that already has a virtualized or hyperconverged data center can transparently implement its contingency data center on a hyperconverged platform. The level of integration is very high.

\section{ACKNOWLEDGEMENTS}

To the Eng. Edgar Rodríguez Romero, IT specialist at the National Superintendence of Sanitation Services of Peru, my colleagues and professors of the Graduate School of the National University Federico Villarreal.

\section{REFERENCES}

1. TELECOMMUNICATIONS INDUSTRY ASSOCIATION, "Telecommunications Infraestructure Standard for Data Centers, TIA 942", (2005)

2. $\quad$ "SE@CE 3.0 - Buscador Público", Prodapp2.seace.gob.pe, (2019). [Online]. Available: http://prodapp2.seace.gob.pe/seacebus-uiwd-pub/buscadorPublico/ buscadorPublico.xhtml. [Accessed: 14- Sep- 2019].

3. "Consulte los procesos de contratación por diferentes criterios de búsqueda", Contratos.gov.co, (2019). [Online]. Available: https://www.contratos.gov.co/consultas/inicioConsulta.do. [Accessed: 14- Sep- 2019].

4. "Ingreso al Sistema - Compras Públicas", Compraspublicas.gob.ec, (2019). [Online]. Available: https://www.compraspublicas.gob.ec/ProcesoContratacion/compras /. [Accessed: 14- Sep- 2019].

5. A.Ortiz, "¿Qué es un data center Tier III-3?", HostDimeBlog, [Online]. Available: https://blog.hostdime.com.co/que-es-data-center-tier-iii-3-especifica ciones. [Accessed: 14- Sep2019]. and Engin and Engin IJRTE 
6. "Best Practices - VMware Support", VMware, (2019). [Online]. Available:

https://www.vmware.com/support/policies/best_practices.html. [Accessed: 14- Sep- 2019].

7. "Magic Quadrant for Hyperconverged Infrastructure", Gartner, (2018). [Online]. Available: https://www.gartner.com/en/documents/3853263/magic-quadrant-f or-hyperconverged-infrastructure0. [Accessed: 14- Sep- 2019].

8. A. Reyes, "Implementación de sistemas hiperconvergentes aplicando la metodología HSA para el proceso de renovación tecnológica en centros de datos", M.S. thesis, Universidad Nacional Federico Villareal, Lima, (2019). [Online]. Available: http://repositorio.unfv.edu.pe/handle/UNFV/3527. [Accessed: 14Sep- 2019].

9. Object Management Group (OMG). Decision Model and Notation, Version 1.0.; Technical Report Formal/2015-09-01; Object Management Group: Needham, MA, USA, (2015)

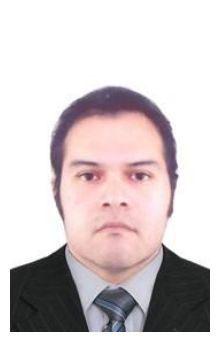

\section{AUTHORS}

Andy Willians Reyes Vargas

Computer and systems engineer and doctoral candidate, specialist in open source solutions by Redhat with the highest current RHCA degree, in addition to other certifications such as RHCE and RHCSA, and specialist in virtualized Data Centers with current certification of the vmWare company as VCP-DCV and the Redhat company as RHCVA.

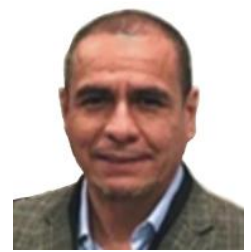

Ciro Rodriguez Rodriguez

Professor at the School of Software Engineering at the National University Mayor de San Marcos and also at the Computer Science School and Graduate School of the National University Federico Villarreal, with science studies at the Abdus Salam International Center for Theoretical Physics (ICTP) and the United States Particle Accelerator School (USPAS)

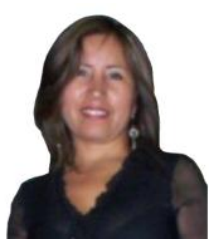

Doris Esenarro Vargas

Professor at the Faculty of Environmental Engineering and Graduate School of the National University Federico Villarreal, with studies in System Engineering, Architecture and Environmental Engineering. 